\title{
PENGARUH PENERAPAN MODEL PEMBELAJARAN KOOPERATIF TIPE NUMBERED HEAD TOGETHER TERHADAP HASIL BELAJAR TEKNIK DASAR PASSING BOLA VOLI
}

\author{
Ida Ayu Kade Geby Gautami ${ }^{1}$, I Putu Darmayasa ${ }^{2}$, Putu Adi Suputra ${ }^{3}$ \\ Jurusan Pendidikan Jasmani, Kesehatan, dan Rekreasi \\ Fakultas Olahraga dan Kesehatan Universitas Pendidikan Ganesha, \\ Kampus Jinang Dalem Undiksha Singaraja, Jalan Jinang Dalem Desa Jinang Dalem \\ Singaraja-Bali Tlp. - \\ e-mail: idabagusdwiwahyudiputra@yahoo.com, iputudarmayasa39@gmail.com,
}

\begin{abstract}
ABSTRAK
Penelitian ini bertujuan untuk mengetahui pengaruh model pembelajaran kooperatif tipe STAD terhadap hasil belajar teknik dasar passing bola voli. Jenis penelitian adalah eksperimen sungguhan (true experimental) dengan rancangan the randomized pretest-posttest control group the same subjec design. Populasi penelitian ini adalah seluruh siswa kelas XI SMA Negeri 2 Banjar tahun pelajaran 2018/2019, keseluruhan kelas berjumlah 8 kelas dengan populasi 259 orang. Pengambilan sampel yang digunakan simple random sampling berdasarkan kelas. Kelas yang menjadi sampel penelitian adalah kelas XI IPS 1 sebagai kelompok eksperimen kelas dan kelas XI IPS 2 sebagai kelompok kontrol. Eksperimen dilakukan sebanyak 3 kali perlakuan diluar pretes-posttest. Data hasil belajar dikumpulkan melalui tes objektif, observasi dan unjuk kerja. Analisis data menggunakan uji-t dengan bantuan SPSS 16.0 for Windows. Rata-rata kelompok eksperimen adalah 0.5 lebih tinggi dari rata-rata kelompok kontrol adalah 0.21. Signifikansi pada uji hipotesis diperoleh melalui uji parametrik (uji Independent Samples Test) adalah 0.000. Disimpulkan bahwa model pembelajaran kooperatif tipe STAD berpengaruh signifikan terhadap hasil belajar teknik dasar passing bola voli. Disarankan kepada guru penjasorkes dapat menerapkan model pembelajaran kooperatif tipe STAD karena terbukti berpengaruh signifikan terhadap hasil belajar siswa.
\end{abstract}

Kata-kata kunci : model pembelajaran kooperatif tipe STAD, hasil belajar teknik dasar passing bola voli.

\begin{abstract}
This research aimed to determine the effect of implementing cooperative learning model study student teams achievement division (STAD) to the learning outcomes of basic techniques of passing volleyball. This research was a true-experimental researching the randomized pretest-posttest control group the same subject design. The research population was students of class XI SMA Negeri 2 Banjar academic year 2018/2019, with the 8 classes and population of the research was 259 peoples. Sampling technique used was simple random sampling based on class. The class into the sample was class XI IPS 1 as experimental group and XI IPS 2 as control group. The experimental was conducted three times treatment outside of pretest-posttest. Data were collected through multiple objective tests, observation and performance tests. Data analysis using t-test with SPSS 16.0 for Windows. Average on experimental group was 0.5 higher than average control was 0.21 . Significance on tests of hypotheses obtained through parametric test (independent Samples Test) was 0.000. Based on the above exposure, implementation of learning model cooperative type NHT effect significantly to the result of learning basic techniques passing volleyballl. It is recommended to the penjasorkes teacher can implement cooperative learning model type STAD because proven effect significantly to the improvement of student's learning outcome.
\end{abstract}

Key words: Cooperative learning model type STAD, learning outcome techniques passing volleyball. 


\section{PENDAHULUAN}

Voli merupakan salah satu jenis permainan olahraga bola besar yang dimainkan oleh enam orang dalam satu tim. Dalam permainan voli ada teknik dasar yang harus dikuasai, diantaranya adalah: a) passing atas, b) passing bawah, c) servis, d) smash, dan e) block. Banyak orang yang bisa bermain voli, namun banyak orang yang tidak bisa menguasai teknik dasar permainan bola voli baik secara teori maupun praktek.

Di SMA Negeri 2 Banjar bola voli menjadi salah satu materi pembelajaran yang masuk ke dalam mata pelajaran penjasorkes. Melihat bahwa untuk mata pelajaran penjasorkes khususnya materi bola voli untuk kelas XI diberikan materi teknik dasar saja, karena untuk teknik lanjutan diberikan di kelas XI dan teknik bermain diberikan di kelas XII. Maka dari itu siswa sebelum siswa menuju ke teknik lanjutan dan bermain, siswa harus benarbenar menguasai dan memahami secara teori maupun praktek mengenai teknik dasar bola voli.

Untuk memudahkan siswa dalam memahami materi pembelajaran, guru diharapkan mampu menerapkan model pembelajaran yang tepat agar bisa meningkatkan motivasi siswa untuk belajar. Namun tidak semua guru bisa menerapkan model pembelajaran yang bervariasi, sehingga siswa cepat bosan dalam mengikuti proses pembelajaran. Hal ini dapat dilihat dari hasil pengamatan yang penulis lakukan di kelas XI SMA Negeri 2 Banjar. Dalam proses mengajar guru penjasorkes masih menggunakan model pembelajaran yang bersifat konvensional, dengan metode ceramah yang sifatnya monoton, sehingga siswa lebih banyak mendengarkan penjelasan dari guru daripada mencoba melakukan gerakan, sehingga siswa menjadi cepat bosan dan hasil belajar yang diperoleh siswa menjadi kurang baik. Selain itu sikap siswa masih pasif saat mengikuti pembelajaran.

Penggunaan model pembelajaran yang masih bersifat konvensional menyebabkan motivasi siswa kurang untuk belajar teknik dasar passing bola voli, karena model pembelajaran yang diterapkan kurang menyenangkan bagi siswa. Selama ini penerapan teknik yang diberikan guru penjasorkes dalam mengajar teknik dasar passing bola voli masih sulit dipelajari oleh siswa, dan mengakibatkan siswa kurang terampil dalam melakukan passing.

Berdasarkan data awal yang peneliti peroleh di kelas kelas XI SMA Negeri 2 Banjar, hasil belajar PJOK peserta didik di kelas XI masih banyak nilai siswa yang tidak memenuhi kriteria ketuntasan minimal (KKM). Nilai KKM di kelas XI adalah 75. Hasil belajar siswa kelas XI SMA Negeri 2 Banjar dari sepuluh kelas dari kelas XI IPA 1 berjumlah 32 orang, kelas XI IPA 2 berjumlah 32 orang, kelas XI IPA 3 berjumlah 32 orang, kelas XI IPS 1 berjumlah 35 orang, kelas XI IPS 2 berjumlah 30 orang, kelas XI IPS 3 berjumlah 32 orang, kelas XI IPS 4 berjumlah 31 orang, dan kelas XI IPS 5 berjumlah 34 orang dengan jumlah keseluruhan 259 orang. Siswa yang nilainya tuntas sebanyak 121 orang $(36,25 \%)$, dan yang tidak tuntas 138 orang $(63,74 \%)$ sehingga dapat disimpulkan bahwa hasil belajar PJOK kelas XI SMA Negeri 2 Banjar dikatakan belum mencapai ketuntasan secara maksimal.

Berdasarkan permasalahan di atas, seorang guru harus bisa menerapkan strategi dalam pembelajaran, sehingga dapat mengacu siswa berperan aktif dalam proses pembelajaran. Oleh karena itu penulis mencoba untuk memberikan solusi alternatif dalam mengatasi permasalahan seperti ini yaitu dengan menerapkan model pembelajaran kooperatif tipe STAD. Adapun kelebihan model pembelajaran STAD ini, antara lain : siswa menjadi lebih siap dalam materi pelajaran, siswa dapat melakukan diskusi dengan sungguh-sungguh, siswa yang pandai dapat membantu siswa yang kurang pandai. Ketertarikan peneliti memilih model pembelajaran kooperatif tipe STAD ini karena (1) model pembelajaran 
kooperatif tipe STAD adalah model pembelajaran sederhana, sehingga cocok diterapkan di SMA N 2 Banjar yang belum pernah menerapkan model pembelajaran STAD ini. (2) Pada model pembelajaran ini siswa lebih banyak mendapat kesempatan untuk melakukan diskusi kelompok dan masing-masing siswa mempunyai tanggung jawab perorangan untuk menguasai materi.

$$
\text { Pemilihan tentang model }
$$

pembelajaran kooperatif tipe STAD ini dikuatkan oleh hasil penelitian-penelitian sebelumnya, diantaranya : (1) Mahardika (2017) menemukan bahwa pengaruh model pembelajaran kooperatif tipe STAD berpengaruh signifikan terhadap hasil belajar teknik dasar passing bola voli dengan angka signifikansi yang diperoleh adalah $\mathrm{p}=0,000<0,05$ pada siswa kelas VII SMP Negeri 3 Sawan tahun pelajaran 2016/2017. (2) Luh Wisma (2017) menemukan bahwa pengaruh pembelajaran kooperatif tipe STAD berpengaruh terhadap hasil belajar teknik passing bola basket dengan angka signifikan pada Uji T adalah 0.005 (3) Kadek Arya Dwi Antara (2017) menemukan bahwa hasil data penelitian berdistribusi normal dan homogen.Uji-t menunjukkan thitung 2.430 sedangkan ttabel sebesar 1.678 dan nilai signifikansi yang diperoleh melalui uji $\mathrm{t}$ adalah 0,019.(4) Yuli Setiawan (2017), model pembelajaran kooperatif tipe STAD berpengaruh sangat signifikan terhadap peningkatan hasil belajar tolak peluru gaya ortodok pada siswa. Dengan demikian disarankan untuk proses pembelajaran guru dapat menerapkan model pembelajaran kooperatif tipe STAD pada materi tolak peluru, karena terbukti berpengaruh sangat signifikan terhadap peningkatan hasil belajar siswa kelas XI SMA Laboratorium Undiksha Singaraja tahun pelajaran 2016/2017.

Dari data nilai yang peneliti dapatkan dan melihat kondisi siswa seperti tersebut, penulis tertarik untuk memberikan solusi dan melaksanakan penelitian lebih mendalam dengan menerapkan model pembelajaran kooperatif tipe Numbered Head together (STAD) untuk meningkatkan hasil belajar siswa.
Berdasarkan latar belakang di atas, permasalahan yang akan dikaji dalam penelitian ini adalah bagaimanakah pengaruh penerapan model pembelajaran kooperatif tipe STAD dapat meningkatkan hasil belajar teknik dasar passing bola voli pada siswa kelas XI SMA Negeri 2 Banjar?

\section{KAJIAN TEORI}

Hasil belajar adalah pola-pola perbuatan, nilai-nilai, pengertian-pengertian, sikap-sikap, apresiasi dan keterampilan" ( Suprijono. 2009 : 5 ). Menurut Dimyati dan Mudjiono ( 2006 : 3 ) Hasil belajar merupakan hasil dari suatu interaksi tindak belajar dan tindak mengajar. Dalam sistem pendidikan nasional, rumusan tujuan pendidikan menggunakan klasifikasi hasil belajar dari Benyamin Bloom yang terdiri dari tiga ranah, yaitu : kognitif (pengetahuan), afekitf (sikap), dan psikomotor (keterampilan).

Permainan bola voli dimainkan oleh dua regu. Setiap regu terdiri atas enam pemain. Bola harus dimainkan secara langsung, artinya bola yang datang dari lawan atau teman harus langsung dipantulkan lagi, tanpa menyentuh lantai, sesuai dengan peraturan.

Menurut Ahmadi Nuril (2007 : 20) permainan bola voli merupakan suatu permainan yang kompleks dan tidak mudah dilakukan oleh setiap orang. Sebab, dalam permainan bola voli dibutuhkan koordinasi gerak yang benar-benar bisa dihandalkan untuk melakukan semua gerakan yang ada dalam permainan bola voli. Dalam permainan bola voli ada beberapa bentuk teknik dasar yang harus dikuasai. Teknik dasar dalam permainan bola voli terdiri atas servis, passing, block, dan smash.

Pembelajaran merupakan proses perubahan tingkah laku yang terjadi pada seseorang yang ditandai dengan terjadinya perubahan tingkat ilmu pengetahuan, keterampilan, atau sikapnya.

adalah penjasorkes pada hakikatnya memanfaatkan aktivitas fisik untuk menghasilkan perubahan holistik dalam kualitas individu, baik dalam hal fisik, 
mental, serta emosional" (Husdarta, 2009:3).

Model pembelajaran adalah suatu perencanaan atau suatu pola yang digunakan sebagai pedoman dalam merencanakan pembelajaran di kelas atau pembelajaran dalam tutorial dan untuk menentukan perangkat-perangkat pembelajaran termasuk di dalamnya bukubuku, film, komputer, kurikulum, dan lainlain. ( Trianto, 2009 : 22). Adapun model pembelajaran yang dapat diterapkan dalam pembelajaran yaitu model pembelajaran langsung, model pembelajaran berdasarkan masalah, model pembelajaran kontekstual, model pembelajaran kooperatif.

Pembelajaran kooperatif adalah model pembelajaran dalam kelompok kecil yang terdiri dari 4-6 orang siswa yang sederajat tetapi heterogen yang satu sama lain saling membantu (Trianto, 2009:56). Adapun tipe-tipe model pembelajaran kooperatif yang digunakan dalam pengajaran, yaitu Tipe Student Teams Achievement Divisions (STAD), Jigsaw, Tipe Group Investigations (GI), Team Games Tournament (TGT), Team Assisted Individualization (TAI), Model Make a Match (Membuat Pasangan), Tipe Think Pair Share (TPS), Tipe Numbered Head Together (NHT). Adapun langkah-langkah model pembelajaran kooperatif yaitu menyampaikan tujuan dan memotivasi siswa, menyajikan informasi, mengorganisasikan siswa ke dalam kelompok, membimbing kelompok bekerja dan belajar, evaluasi, dan memberikan penghargaan.

Students Teams Achievement Division (STAD) merupakan salah satu jenis pembelajaran kooperatif yang paling sederhana. Slavin (dalam Trianto, 2007: 52) menyatakan bahwa pada STAD siswa ditempatkan dalam tim belajar yang beranggotakan 4-5 orang yang merupakan campuran menurut tingkat prestasi, jenis kelamin, dan suku. Guru menyajikan pelajaran, dan selanjutnya siswa bekerja dalam tim mereka dan memastikan seluruh anggota tim telah menguasai pelajaran tersebut. Kemudian siswa diberikan tes tentang materi tersebut, pada saat tes ini mereka tidak diperbolehkan saling membantu.

Kelebihan model pembelajaran kooperatif tipe STAD adalah (1) Siswa lebih mampu mendengarkan, menerima dan menghormati serta menerima orang lain.(2) Siswa mampu mendefinisikan akan perasaannya, dan juga perasaan orang lain, (3) .

Model pembelajaran konvensional adalah model pembelajaran yang berpusat pada guru, yang penyampaian materinya lebih banyak secara lisan, dan siswa harus teliti dalam menyimak informasi. "Pembelajaran konvensional dimulai dengan apersepsi, penyajian informasi, pemberian soal, tugas dan simpulan" (Suryosubroto, 2002:71).

Tujuan penelitian ini adalah untuk mengetahui pengaruh penerapan model pembelajaran kooperatif tipe Numbered Head Together (NHT) terhadap hasil belajar teknik dasar passing bola voli pada siswa kelas VIII SMP Negeri 1 Seririt tahun pelajaran 2017/2018.

\section{METODE Rancangan Penelitian}

Rancangan penelitian adalah "rencana tantang bagaimana cara mengumpulkan, menyajikan, dan menganalisa data untuk memberi arti terhadap data tersebut secara efektif dan efesien" (Kanca Nyoman, 2010: 55). Rancangan pada penelitian ini adalah rancangan the randomized pretest-postest control group the same subject design. 


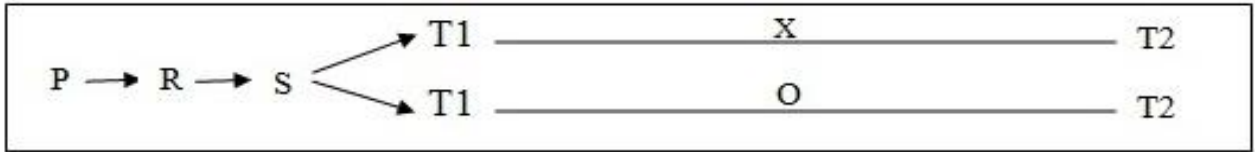

Gambar 01.

Rancangan penelitian (Kanca Nyoman, 2010: 87)

Keterangan:

$\mathrm{P} \quad=$ Populasi

$\mathrm{R} \quad=$ Random

$\mathrm{S} \quad=$ Sampel

T1 = Tes Awal (pretest)

T2 = Tes Akhir (posttest)

$\mathrm{X}=$ Kelompok Eksperimen menggunakan metode pebelajaran NHT.

$\mathrm{O}=$ Kelompok Kontrol menggunakan metode Jenis Penelitian pembelajaran ceramah.

Jenis penelitian yang digunakan dalam penelitian ini adalah eksperimen sungguhan (true experimental). "Tujuan dari penelitian eksperimen sungguhan adalah untuk menyelidiki kemungkinan saling hubungan sebab-akibat dengan cara mengenakan kepada satu atau lebih kelompok eksperimental satu atau lebih kondisi perlakuan dan memperbandingkan hasilnya dengan satu atau lebih kelompok kontrol yang tidak dikenai kondisi perlakuan"(Kanca Nyoman, 2010: 86).

\section{Populasi dan Sampel}

Pada penelitian yang dilakukan di SMP Negeri 1 Seririt tahun pelajaran 2017/2018 jumlah keseluruhan populasi yaitu 258 siswa dengan 8 kelas.Penelitian ini menggunakan simple random sampling yang digunakan pada populasi kelas yang homogen. Sampel pada penelitian adalah seluruh siswa kelas VIII SMP Negeri 1 Seririt tahun pelajaran 2017/2018 yang terdistribusi ke dalam 2 kelas yaitu: VIII A berjumlah 32 orang dan VIII C berjumlah 31 orang, sehingga keseluruhan jumlah sampel penelitian adalah 63 orang.

\section{Variabel}

Penelitian ini terdiri dari dua variabel yaitu variabel terikat (hasil belajar teknik dasar passing bola voli) dan variabel bebas (model pembelajaran kooperatif tipe NHT dan model pembelajaran konvensional). Metode dan Instrumen Pengumpulan Data

Pengumpulan data dilakukan dengan penilaian aspek kognitif oleh peneliti berupa pre-test dan post-test, penilaian aspek afektif oleh kedua evaluator, dan penilaian aspek psikomotor oleh kedua evaluator. Jenis instrumen yang digunakan adalah asesmen teknik dasar passing bola voli. Data tentang hasil belajar siswa dilakukan dengan menggunakan instrumen berupa asesmen hasil belajar teknik dasar passing bola voli.

\section{Metode dan Teknik Analisis Data}

Data yang diperoleh diuji dengan uji normalitas dan homogenitasnya. Analisis data pada penelitian ini akan menggunakan program SPSS 16.0 for Windows.Hal tersebut dilakukan untuk memperoleh simpulan.

\section{HASIL PENELITIAN DAN PEMBAHASAN Deskripsi Data}

Data hasil belajar penjasorkes siswa diperoleh dari hasil pre-test dan post-test yang diberikan kepada kedua kelompok sampel (dapat dilihat pada lampiran). Rangkuman analisis data hasil belajar pendidikan jasmani olahraga dan kesehatan siswa pada kedua sampel dapat dilihat pada Tabel 01 berikut. 
Tabel 01.

Rangkuman Analisis Nilai Hasil Belajar Teknik Dasar Passing Bola Voli

\begin{tabular}{cccc}
\hline \multirow{2}{*}{ No } & \multirow{2}{*}{ Variabel } & \multicolumn{2}{c}{ Kelompok Sampel } \\
\cline { 3 - 4 } & & Eksperimen & Kontrol \\
\hline 1. & Jumlah Siswa & 32 & 31 \\
\hline 2. & Rata-rata nilai & 0,5 & 0,21 \\
\hline 3. & Standar Deviasi & 0,071 & 0,089 \\
\hline
\end{tabular}

Berdasarkan tabel $01 \mathrm{di}$ atas tentang hasil belajar passing bola voli kelompok eksperimen dan kelompok kontrol dengan jumlah masing-masing kelas 32 orang dan 31 orang diperoleh rata-rata nilai kelompok eksperimen 0,5 , sedangkan kelompok kontrol 0,21 dengan standar deviasi pada kelompok eksperimen 0,071 dan kelompok kontrol 0,089 .

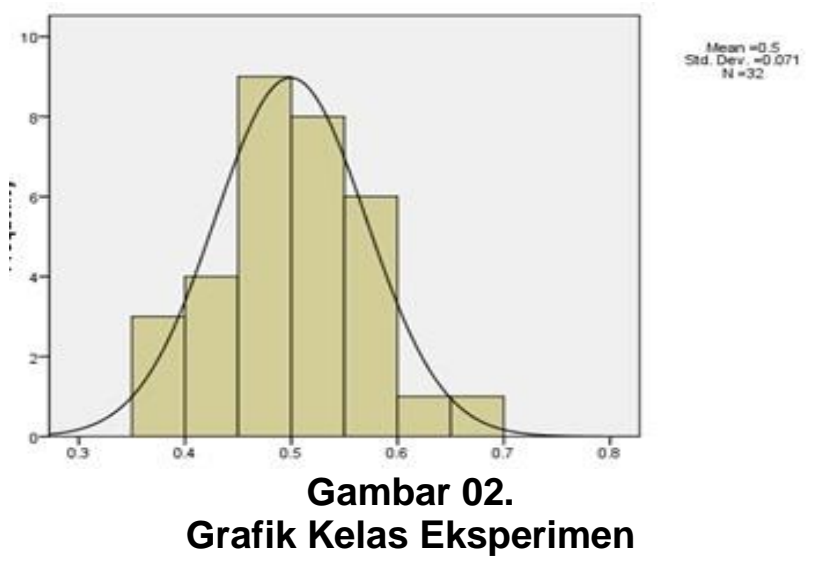

Histogram kelas eksperimen di atas menunjukan bahwa data kelas eksperimen berdistribusi normal. Dapat dilihat dari bentuk kurva yang simetris $x=$. . Dengan rata-rata 0,5 setelah dihitung dengan gainskor
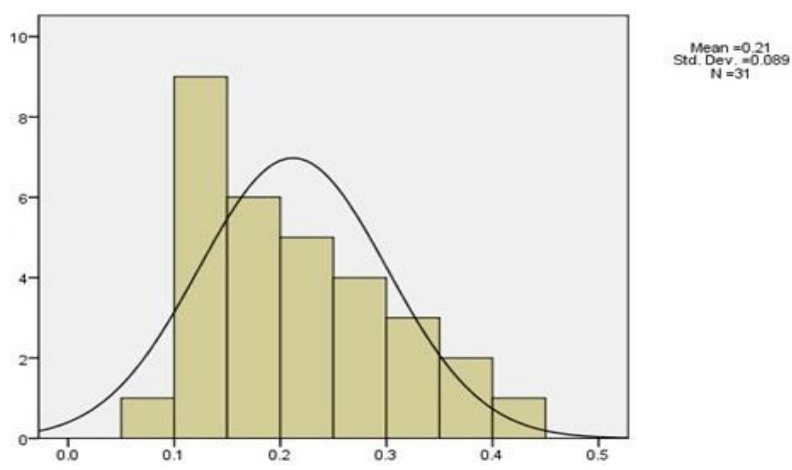

Gambar 03.

Grafik Kelas Kontrol

Histogram kelas kontrol di atas menunjukan bahwa data kelas kontrol berdistribusi normal. Dapat dilihat dari bentuk kurva yang simetris $\mathrm{x}=$. . Dengan rata-rata 0,21 setelah dihitung dengan gainskor.

Berdasarkan gambar 4.1 dan 4.2 di atas menunjukan bahwa rata-rata nilai hasil 
belajar kelas eksperimen lebih tinggi dibandingkan dengan kelas kontrol.

\section{Pengujian Hipotesis Penelitian}

Untuk mengetahui kebenaran dari hipotesis dalam penelitian ini, digunakan Uji-t. Namun, sebelumnya dilakukan uji prasyarat pengujian yaitu uji normalitas dan uji homogenitas terhadap tes hasil belajar pendidikan jasmani olahraga dan kesehatan.

\section{Uji Normalitas}

Uji normalitas sebaran data dilakukan menggunakan rumus Kolmogorov-Smirnov pada signifikansi 0,05. Jika $p>0,05$ data berdistribusi normal, sebaliknya jika $p<0,05$ data tidak berdistribusi normal. Data yang dianalisis adalah gain score. berdasarkan analisis yang telah dilakukan dengan menggunakan aplikasi SPSS 16.00 for Windows. Adapun hasil pengujian normalitas sebaran data dengan uji Kolmogorov-Smirnov, dapat dilihat pada tabel 02.

Tabel 02.

Hasil Uji Normalitas Sebaran Data

\begin{tabular}{lccc}
\hline \multirow{2}{*}{ Kelas } & \multicolumn{3}{c}{ Kolmogorov-Smirnov $^{\mathrm{a}}$} \\
\cline { 2 - 4 } & Statistic & Df & Sig. \\
\hline gain score kelas eksperimen & .103 & 32 & $.200^{*}$ \\
\hline gain score kelas control & .134 & 31 & .165 \\
\hline
\end{tabular}

Berdasarkan Tabel 02 di atas, terlihat bahwa untuk semua kelompok signifikansi pada uji Kolmogorov-Smirnov lebih besar dari 0,05. Dengan demikan maka semua sebaran data berdistribusi normal.

\section{Uji Homogenitas}

Uji homogenitas varian dilakukan dengan pengelompokan berdasarkan model pembelajaran, yaitu model pembelajaran kooperatif tipe Numbered Head Together (NHT) dengan model pembelajaran konvensional. Uji homogenitas varians antar kelompok dilakukan dengan bantuan SPSS 16.00 for Windows dengan menggunakan
Levene's Test Of Equality Error Variance. Hipotesis statistik yang diuji dalam pengujian homogenitas adalah sebagai berikut.

$H_{0}$ : variansi pada setiap kelompok adalah sama (homogen)

$H_{a}$ : variansi pada setiap kelompok tidak sama (tidak homogen)

Dengan kriteria pengujian yang digunakan adalah terima $H_{0}$ jika nilai $p>$ 0,05 dimana data memiliki varians yang sama apabila angka signifikansi yang dihasilkan lebih dari 0,05. Rangkuman hasil perhitungan homogenitas data menggunakan SPSS 16.00 for Windows dapat dilihat pada Tabel 03 berikut.

Tabel 03.

Rangkuman Hasil Uji Homogenitas

\begin{tabular}{cccc}
\hline Levene Statistic & df1 & df2 & Sig. \\
\hline 1.855 & 1 & 61 & .178 \\
\hline
\end{tabular}

Berdasarkan Tabel 03, hasil uji Levene's menunjukkan bahwa untuk hasil belajar teknik dasar passing bola voli siswa taraf signifikansi $0,178>0,05$. Dapat 
disimpulkan bahwa variansi pada setiap kelompok adalah sama (homogen).

\section{Uji Hipotesis}

Pengujian hipotesis menggunakan uji- $t$ dengan bantuan SPSS 16.00 for Windows. Karena variansi normal dan homogen, maka dipilih parametrik (uji independent sampel T-test dengan bantuan SPSS 16.00 for Windows), data yang dianalisis adalah gain skor. Hasil analisis dengan uji independen sampel t-test disajikan pada tabel 04.

Tabel 04.

Hasil dari Independen Sampel Test

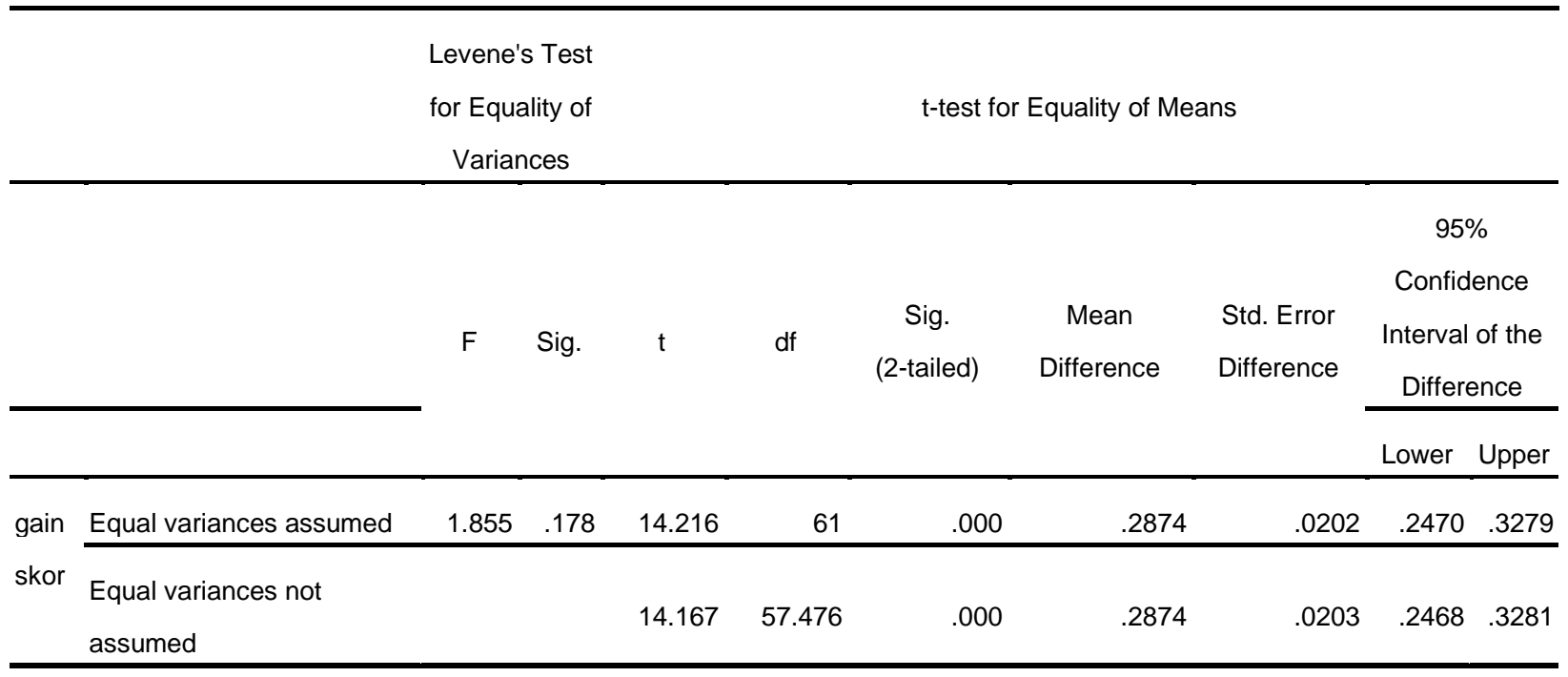

Dari tabel 04 menunjukan bahwa $p<$ 0,05 , karena nilai signifikasinya adalah 0,000. Hal ini menyatakan bahwa terdapat perbedaan hasil belajar teknik dasar passing atas dan passing bawah antara siswa yang diberi perlakuan dengan model pembelajaran kooperatif tipe NHT dengan siswa yang diberi perlakuan dengan model pembelajaran konvensional. Sehingga model pembelajaran kooperatif tipe NHT berpengaruh signifikan terhadap hasil belajar teknik dasar passing atas dan passing bawah bola voli pada siswa kelas VIII SMP Negeri 1 Seririt.

\section{Pembahasan}

Pada penelitian ini masing-masing kelompok penelitian diberikan perlakuan yang berbeda, dimana kelompok eksperimen diberikan perlakuan berupa model pembelajaran kooperatif tipe NHT sedangkan pada kelompok kontrol diberikan perlakuan model pembelajaran konvensional. Pembelajaran koperatif tipe
NHT menghendaki siswa bekerja saling membantu dalam kelompok kecil dan lebih dicirikan oleh penghargaan kooperatif daripada penghargaan individual. Pendekatan ini dirancang untuk mengembangkan indikator-indikator kunci pembelajaran kooperatif yang meliputi saling ketergantungan positif, tanggung jawab perseorangan, dan partisipasi yang merata. Dalam pendekatan struktural, tujuan kognitif yang hendak dicapai adalah berupa informasi akademik sederhana, sedangkan tujuan sosialnya adalah keterampilan kelompok dan keterampilan sosial. Struktual tim beranggotakan 3-5 orang tiap kelompok. Dalam pembelajaran kelompok kontrol yang dibelajarkan menggunakan model pembelajaran konvensional menekankan pada guru sebagai pusat informasi dan siswa sebagai penerima informasi. Situasi kelas sebagian besar masih berfokus pada guru sebagai sumber utama pengetahuan, serta 
pengguanaan model ceramah sebagai pilihan utama strategi belajar mengajar.

Pembelajaran yang dilaksanakan di kelompok kontrol dilaksanakan dengan menerapkan model pembelajaran konvensional. Pembelajaran dikelompok kontrol dilakukan dengan model ceramah oleh guru dalam penyampaian materi kemudian mendemonstrasikan materi pelajaran dan menugaskan siswa untuk mempraktikkan materi yang diajarkan. Melalui penugasan tersebut diharapkan siswa mampu memahami dan melakukan gerakan dengan benar.

Berdasarkan pengamatan peneliti pada saat pembelajaran berlangsung, model konvensional yang diterapkan di kelompok kontrol pada dasarnya telah menuntun siswa untuk dapat memahami dan mempraktikan gerakan dengan benar. Namun dengan penggunaan model ceramah dalam penyampaian materi pelajaran menyebabkan pembelajaran berpusat pada guru dan masih banyak siswa yang kurang aktif. $\mathrm{Hal}$ ini mengakibatkan kurangya partisipasi siwa secara menyeluruh dalam proses belajar mengajar atau hanya siswa yang memiliki kemampuan lebih saja yang mau aktif dalam proses pembelajaran, sehingga pemahaman dan keterampilan siswa dalam melakukan teknik dasar passing bola voli menjadi terhambat dan tidak merata. Hal ini berbeda dengan pembelajaran pada kelompok eksperimen dengan menggunakan model pembelajaran kooperatif tipe NHT dimana siswa yang yang dibelajarkan melalui kelompokkelompok kecil yang setiap anggota di dalam kelompoknya diberikan nomor per kepala yang akan digunakan guru menunjuk salah satu siswa pada masing-masing kelompok untuk menjelaskan hasil diskusi kelompoknya. Hal tersebut dapat memberikan tanggung jawab pada seluruh anggota kelompok untuk memahami materi yang diajarkan sehingga akan melibatkan partisipasi seluruh siswa. Faktor-faktor tersebutlah yang mengakibatkan pembelajaran yang berlangsung di kelompok eksperimen mendapat respon yang lebih baik dari siswa sehingga ratarata skor siswa di kelompok eksperimen lebih tinggi daripada rata-rata skor siswa pada kelompok kontrol.

Hasil belajar siswa yang lebih baik dengan menggunakan model pembelajaran NHT juga dikuatkan oleh peneliti sebelumnya diantaranya yaitu : (1) Fajrin (2014) menemukan bahwa pembelajaran dengan menggunakan model kooperatif tipe $\mathrm{NHT}$ memberikan pengaruh yang signifikan terhadap hasil belajar dribbling sepakbola dengan nilai $t_{\text {hitung }} 18,58>t_{\text {tabel }} 1,69$. (2) Aprida (2014) juga menemukan bahwa pembelajaran dengan menggunakan model pembelajaran kooperatif tipe Numbered Head Together (NHT) berpengaruh signifikan terhadap hasil belajar siswa pada materi pokok besaran dan satuan di kelas VII SMP Negeri 1 Bakongan, dengan nilai $t$ hitung $>$ t tabel yaitu 2,690 >2,00.

Dari uraian diatas memberikan gambaran bahwa model pembelajaran kooperatif tipe NHT dalam pembelajaran teknik dasar passing bola voli berpengaruh positif terhadap hasil belajar siswa. Hasil penelitian ini memberikan implikasi bahwa terdapat perbedaan hasil belajar teknik dasar passing bola voli antara siswa yang dibelajarkan menggunakan model pembelajaran kooperatif tipe NHT dengan siswa yang dibelajarkan dengan menggunakan model pembelajaran konvensional.

\section{Implikasi}

Implikasi yang ditimbulkan dengan adanya pengaruh penerapan Model Pembelajaran Kooperatif Tipe NHT terhadap Hasil Belajar Penjasorkes adalah sebagai berikut :

1. Pengaruh penerapan model pembelajaran kooperatif tipe NHT dalam pembelajaran dapat mengatasi siswa yang kurang aktif dalam mengikuti pembelajaran.

2. Pembelajaran menggunakan model kooperatif tipe NHT dapat meningkatkan motivasi dan minat siswa dalam belajar. 


\author{
Siswa menjadi terbiasa tampil di \\ depan temannya sehingga dapat \\ meningkatkan percaya diri.
}

\section{SIMPULAN DAN SARAN}

Berdasarkan hasil analisis data dan pembahasan dapat disimpulkan bahwa Pengaruh model pembelajaran kooperatif tipe Numbered Head Together (NHT) berpengaruh signifikan terhadap peningkatan hasil belajar teknik dasar passing bola voli pada siswa kelas VIII SMP Negeri 1 Seririt tahun pelajaran 2017/2018. Saran yang dapat disampaikan dari penelitian terdapat dua saran yaitu:

1. Bagi guru Penjasorkes, model pembelajaran kooperatif tipe NHT dapat dijadikan salah satu alternatif model pembelajaran yang dapat diterapkan di lapangan untuk membangun keaktifan siswa pada pembelajaran Penjasorkes mengingat memberikan pengaruh positif terhadap hasil belajar siswa.

2. Bagi peneliti lain yang tertarik meneliti permasalahan ini, disarankan untuk meneliti variabel terikat lain, menggunakan materi yang lain dengan memperhatikan kendala-kendala yang telah dihadapi oleh peneliti selama penelitian.

\section{DAFTAR PUSTAKA}

Ahmadi, Nuril. 2007. Permainan Bola Voli. Surakarta : Era Pustaka Utama

Aprida, Nurfiza. 2014. "Pengaruh Model Pembelajaran Kooperatif Tipe Number Head Together (NHT) Terhadap Hasil Belajar Siswa Pada Materi Pokok Besaran Dan Satuan Dikelas VIII SMP Negeri 1 Bakongan". Tersedia pada:(diakses pada tanggal 14 Juni Desember 2018).

Dimiyati dan Mudjiono. 2006. Belajar Pembelajaran. Jakarta : PT Rineka Cipta.
Fajrin, Yanuar N. 2014. "Pengaruh Penerapan Model Pembelajaran Kooperatif Tipe Numbered Head Together (NHT) Terhadap Hasil Belajar Dribbling Sepakbola (Studi Pada Siswa Kelas XI SMA Negeri 1 Tarik Sidoarjo)". Tersedia pada http://ejournal.unesa.ac.id/index.ph p/jurnal-pendidikanjasmani/article/view/9967 Vol 2, No 2. (diakses pada tanggal 14 Juni Desember 2018).

Haris Kusuma Wardana, I Made, dkk. 2017. Belajar Teknik Dasar Pengaruh Penerapan Model Pembelajaran Kooperatif Tipe NHT Terhadap Hasil Passing Bola Basket: Pendidikan Jasmani Kesehatan Dan Rekreasi Vol 8, No 2, Fakultas Olahraga Dan Kesehatan. Tersedia Pada:

https://ejournal.undiksha.ac.id/index .php/JJP/article/view/11268/7197.

(diakses pada tanggal 22 Juni Desember 2018).

Husdarta.2009. Manajemen Pendidikan Jasmani. Bandung: Alfabeta.

Kanca, I Nyoman. 2010. Metode Penelitian Pengajaran Pendidikan Jasmani dan Olahraga. Singaraja: Universitas Pendidikan Ganesha.

Ngurah Budi Tri Adnyana, I Gusti 2017. Pengaruh Model Pembelajaran Kooperatif Tipe NHT Terhadap Hasil Belajar Teknik Dasar Passing Sepak Bola (Kaki Bagian Dalam Dan Kaki Bagian Luar) Pada Siswa Kelas VII SMP Negeri 4 Singaraja Tahun Pelajaran 2016/2017. https://ejournal.undiksha.ac.id/index. php/JJP/article/view/11253/7188 (diakses pada tanggal 23 Juni 2018).

Suryosubroto. 2002. Proses Belajar Mengajar Di Sekolah. Jakarta : PT. Rineka Cipta. 
Satriawan, Kadek, dkk. 2017. Pengaruh Model Pembelajaran Kooperatif Tipe NHT (Numbered Head Together) Terhadap Hasil Belajar Teknik Dasar Passing Bola Voli. Pendidikan Jasmani Kesehatan Dan Rekreasi Vol 8, No 2, Fakultas Olahraga Dan Kesehatan. Tersedia pada:

https://ejournal.undiksha.ac.id/index .php/JJP/article/view/11266/7195. (diakses pada tanggal 22 Juni 2018).

Setiawan, Yuli, dkk. 2017. Pengaruh Model Pembelajaran Kooperatif Tipe NHTTerhadap Hasil Belajar Tolak Peluru Gaya Ortodok: Pendidikan Jasmani Kesehatan Dan Rekreasi Vol 8, No 2, Fakultas Olahraga Dan Kesehatan. Tersedia pada: https://ejournal.undiksha.ac.id/index .php/JJP/article/view/11286/721

(diakses pada tanggal 23 Juni 2018)

Trianto. 2009. Model-Model Pembelajaran Inovatif Berorientasi Konstruktivistik. Jakarta: Prestasi Pustaka Publisher.

Yulia Sandra Anabella (2017), Pengaruh Model Pembelajaran Kooperatif Tipe Nht Terhadap Hasil Belajar Teknik Dasar Passing Bola Voli. Pendidikan Jasmani Kesehatan dan Rekreasi Vol 8, No 2. Fakultas Olahraga dan Kesehatan. Tersedia pada

https://ejournal.undiksha.ac.id/index
.php/JJP/article/view/11270/7199. (diakses pada tanggal 22 Juni Desember 2018). 